\title{
Geochemistry of Tidal Flat Brines at Umm Said, SE Qatar, Persian Gulf
}

\author{
K. de Groot $^{1}$
}

\section{$\underline{\text { ABSTRACT }}$}

The landward part of the $7 \mathrm{~km}$ wide sabkha at Umm Said, SE Qatar, is filled with a stagnant brine virtually saturated with halite. Recent dolomite occurs in the sabkha sediments, the quantity being fully accounted for by the amount of $\mathrm{Mg}^{++}$ions lost from the interstitial brine.

The existence of a reflux system in the seaward parts of the sabkha was established. It was not, however, possible to give any unequivocal demonstration of the effect of this potential system for dolomitization. Although both a reflux mechanism and Recent dolomite formation occur in this tidal flat, the first process has apparently not influenced the second sufficiently to permit the demonstration of reflux dolomitization.

\section{INTRODUCTION}

Refluxing of hypersaline waters through carbonate sediments has been postulated by Adams and Rhodes (1960) as a mechanism for the formation of dolomite. This process involves flowing of sea water into, or over, coastal sediments in hot, arid climates. Evaporation results in the precipitation of gypsum and the $\mathrm{Mg} / \mathrm{Ca}$ ratio in the water is thus increased. The dense, $\mathrm{Mg}^{++}$- rich water transforming calcite or aragonite to dolomite, flows downwards through the sediment and returns ultimately to the sea.

At some localities where Recent dolomite has been found, including the Pekelmeer on the isle of Bonaire, (Deffeyes et a1.;1965), and Sabkha Faishakh on the W coast of Qatar (Illing et al., 1965), a study of the water chemistry has been made to evaluate whether the reflux model was operating. Studies by van der Poel (unpublished She11 Research report) indicated that refluxing of hypersaline water did not seem to be occurring in Sabkha Faishakh and subsequent studies in the Pekelmeer did not support earlier calculations. On the contrary, all water analyses made, both in Faishakh and in the Pekelmeer sediment, showed that hypersaline water in the sediment in which the dolomite was probably forming overly less dense, and thus less saline, water. Van der Poel concluded from his data obtained on Sabkha Faishakh that the poor vertical permeability of the sediment apparently prevented vertical fluid flow and thus reflux.

1 Shell Research B.V., Rijswijk, The Netherlands. 
Subsequent work by Murray (1969) on the hydrology of South Bonaire furnished evidence for influx of seawater into the Pekelmeer through permeability conduits in the underlying rock. However, during early summer a major reflux event is suggested: heavy brine from the Pekelmeer then flows back to the sea through the same conduits that supply the sea water during most of the year. Thus reflux dolomitization of the underlying rock is quite possible, although Murray did not report mineralogical data showing effective dolomitization of these rocks.

Studies by E.A. Shinn on the siliciclastic Umm Said Sabkha (described elsewhere in this volume) offered the opportunity of studying the water chemistry of a sabkha which, because of its homogeneous, sandy nature, was likely to have a greater vertical permeability than the areas previously examined (discussed above). It was considered, furthermore, that the distribution of Recent dolomite might give an indication of the effect of any existing reflux system.

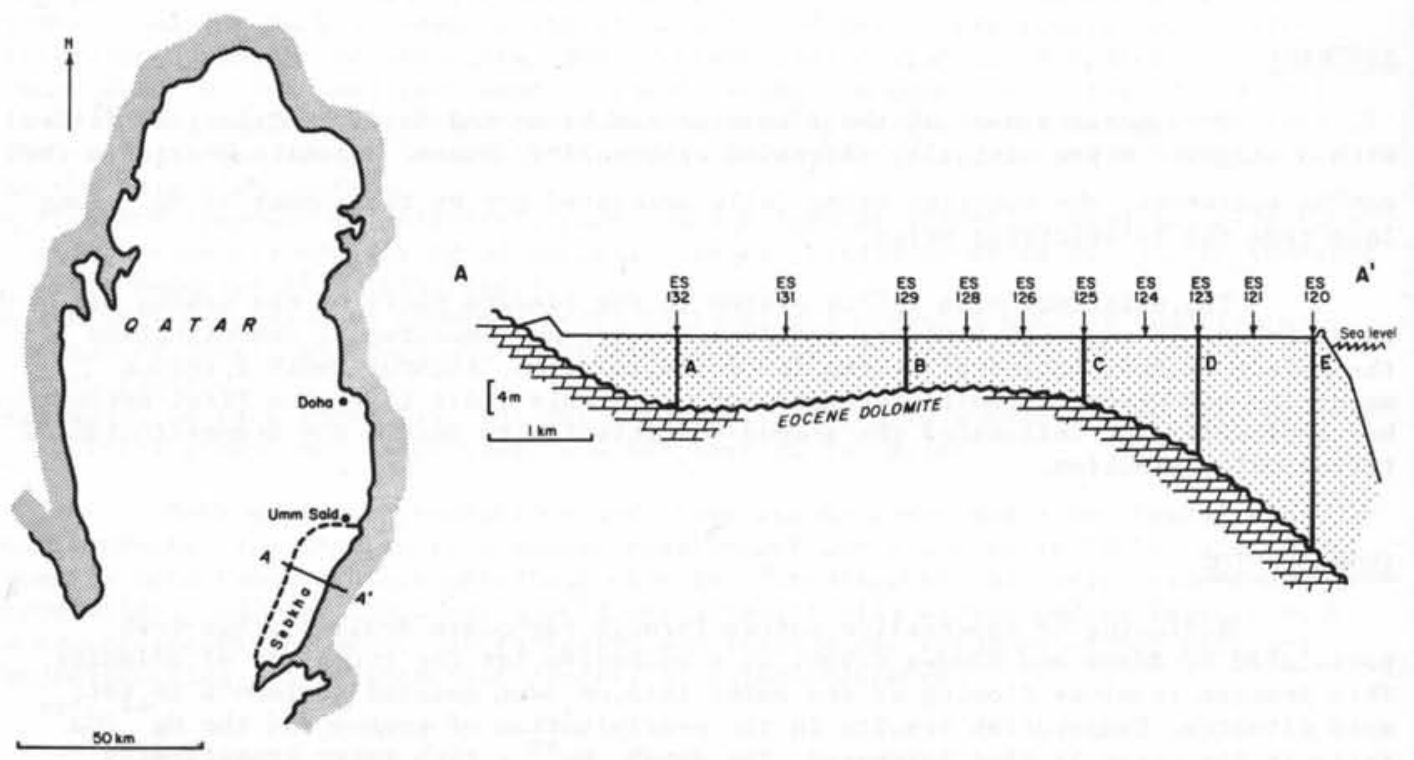

Fig. 1. Profile across $7.5 \mathrm{~km}$ wide sabkha south of Umm Said, Qatar. Section based on wells A, B, C, D, E.

Water sample pits ES 120-132 are shown by arrows

\section{ANALYTICAL AND SAMPLING METHODS}

\section{Sampling}

A series of five, continually-cored wells was drilled across the Umm Said Sabkha, their locations being illustrated by Shinn elsewhere in this volume. Between these wells shallow pits were dug for water sampling, (indicated by arrows, Fig. 1), sabkha brines flowing into these pits from the sides and from below. Water level was about $50 \mathrm{~cm}$ below the sabkha surface.

\section{Water analysis}

While some water samples were taken from the pits, most were obtained from cores. After opening the core tubes in the laboratory, the bottom $10 \mathrm{~cm}$ was immediately transferred to a filter centrifuge for water extraction. This water was analyzed for chloride, calcium and magnesium and, in a few cases, also for sulphate. Analysis 


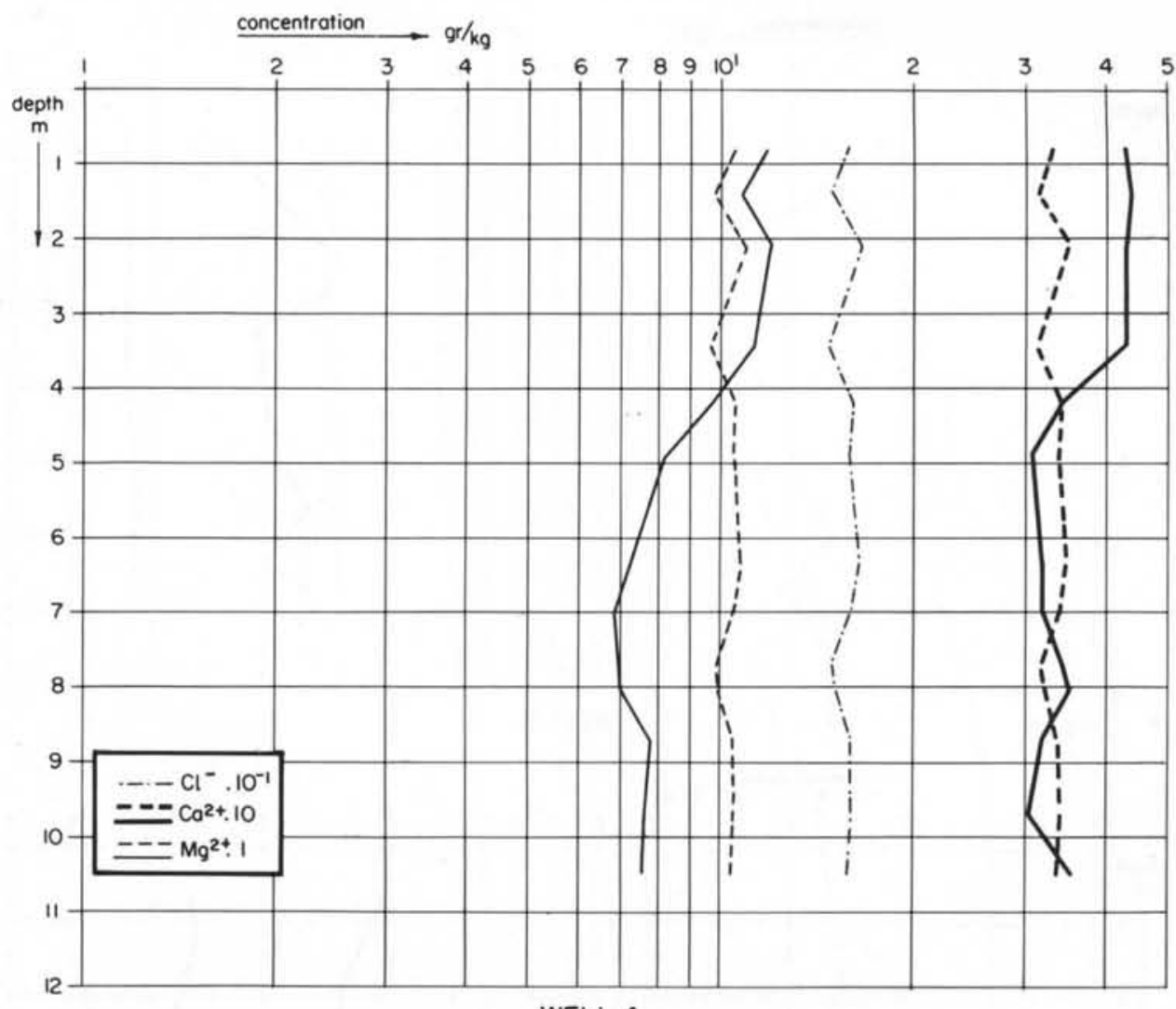

WELL A

$=\Xi=-\begin{aligned} & \text { Represent the } \mathrm{Ca}^{2+} \mathrm{ond}_{\mathrm{Mg}}^{2+} \text { concentrations which would exist if only concentrotion of the woter had token ploce } \\ & \text { without } \mathrm{Ca}^{2+} \text { or } \mathrm{Mg}^{2}+\mathrm{loss}^{2}\end{aligned}$ Actual concentrations

Fig. 2A. Comparison of concentrations of $\mathrm{Ca}^{2+}$ and $\mathrm{Mg}^{2+}$ with the $\mathrm{Cl}$-concentration in the interstitial water as a function of depth 


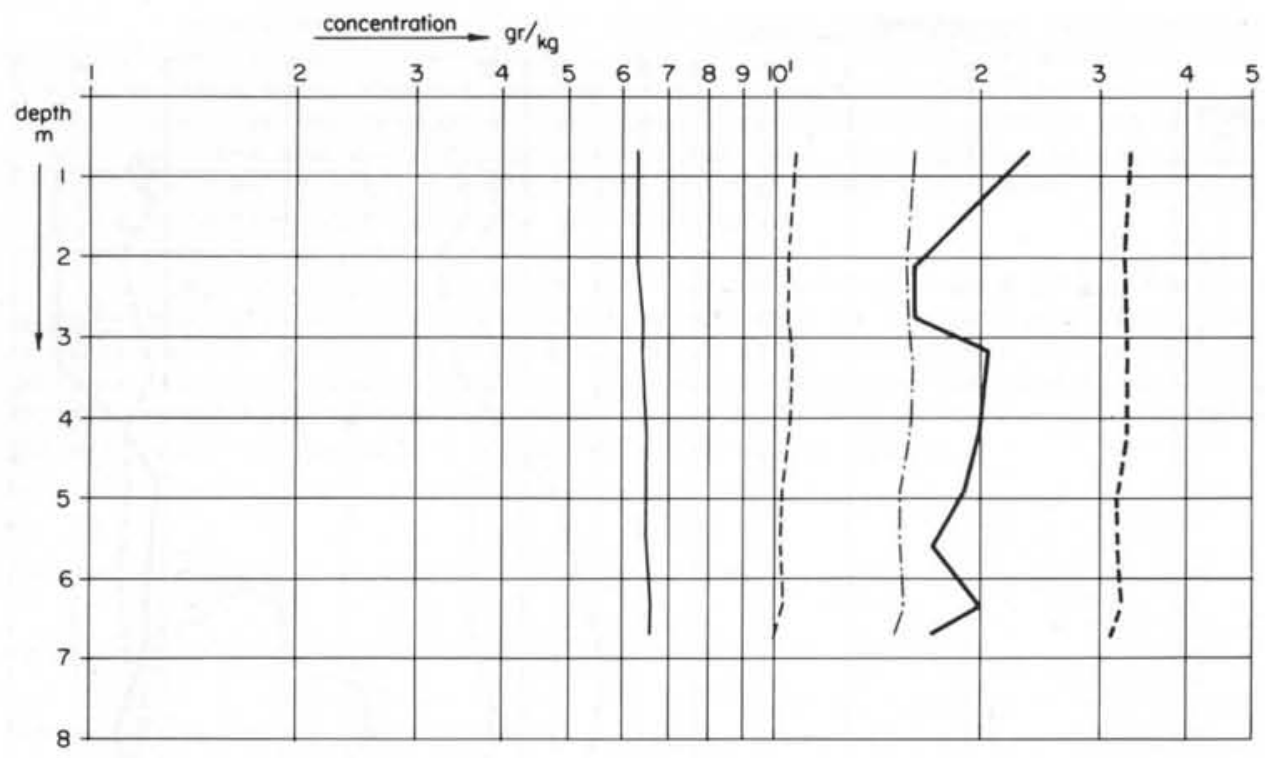

Fig. 28

WELL B

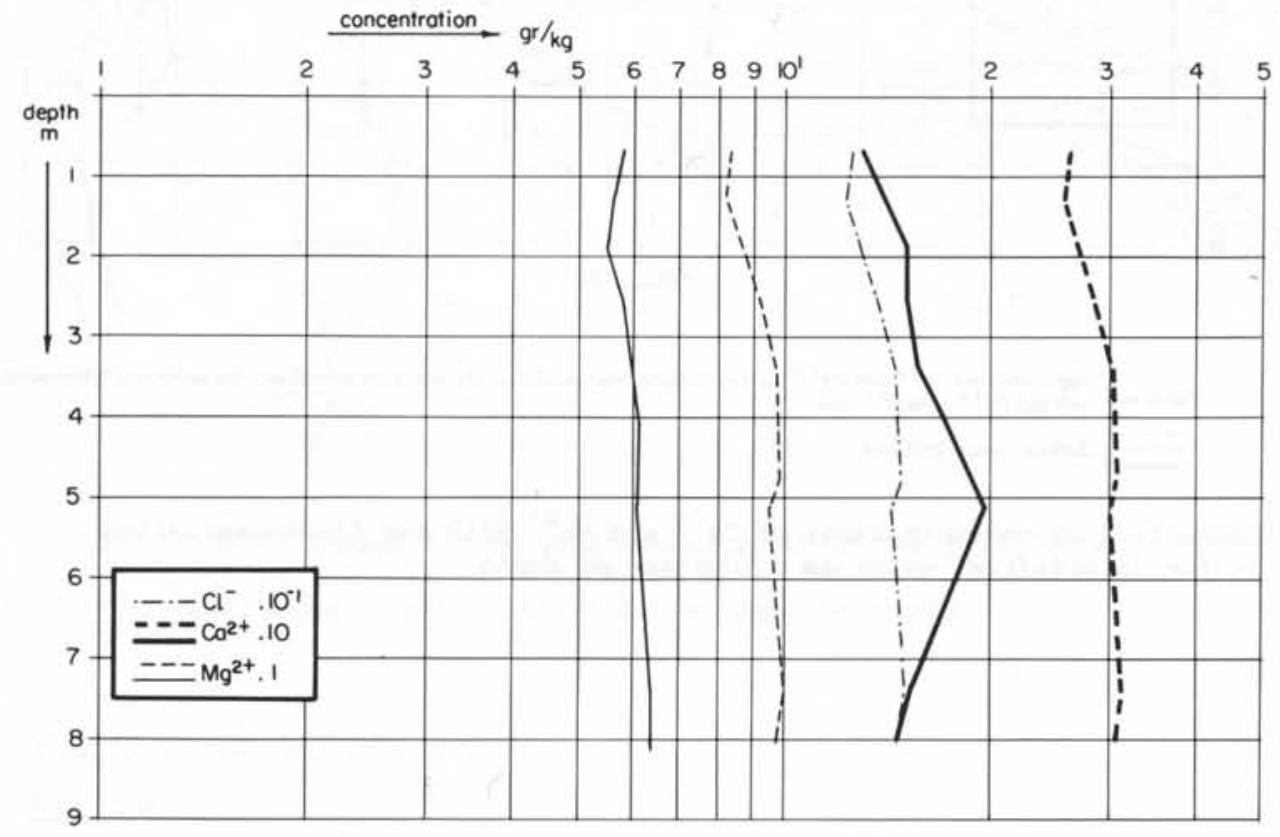

Fig. 2C

WELL C

\section{ニ-ニ- Represent the $\mathrm{Co}^{2+}$ and $\mathrm{Mg}^{2+}$ concentrations which would exist if only concentration of the water had token ploce
without $\mathrm{Ca}^{2+}$ or $\mathrm{Mg}^{2+}$ loss}

=-.- Actual concentrations

Fig. 2B and $\mathrm{C}$. Comparison of concentrations of $\mathrm{Ca}^{2+}$ and $\mathrm{Mg}^{2+}$ with the $\mathrm{Cl}^{-}-\mathrm{con}-$ centration in the interstitial water as a function of depth 


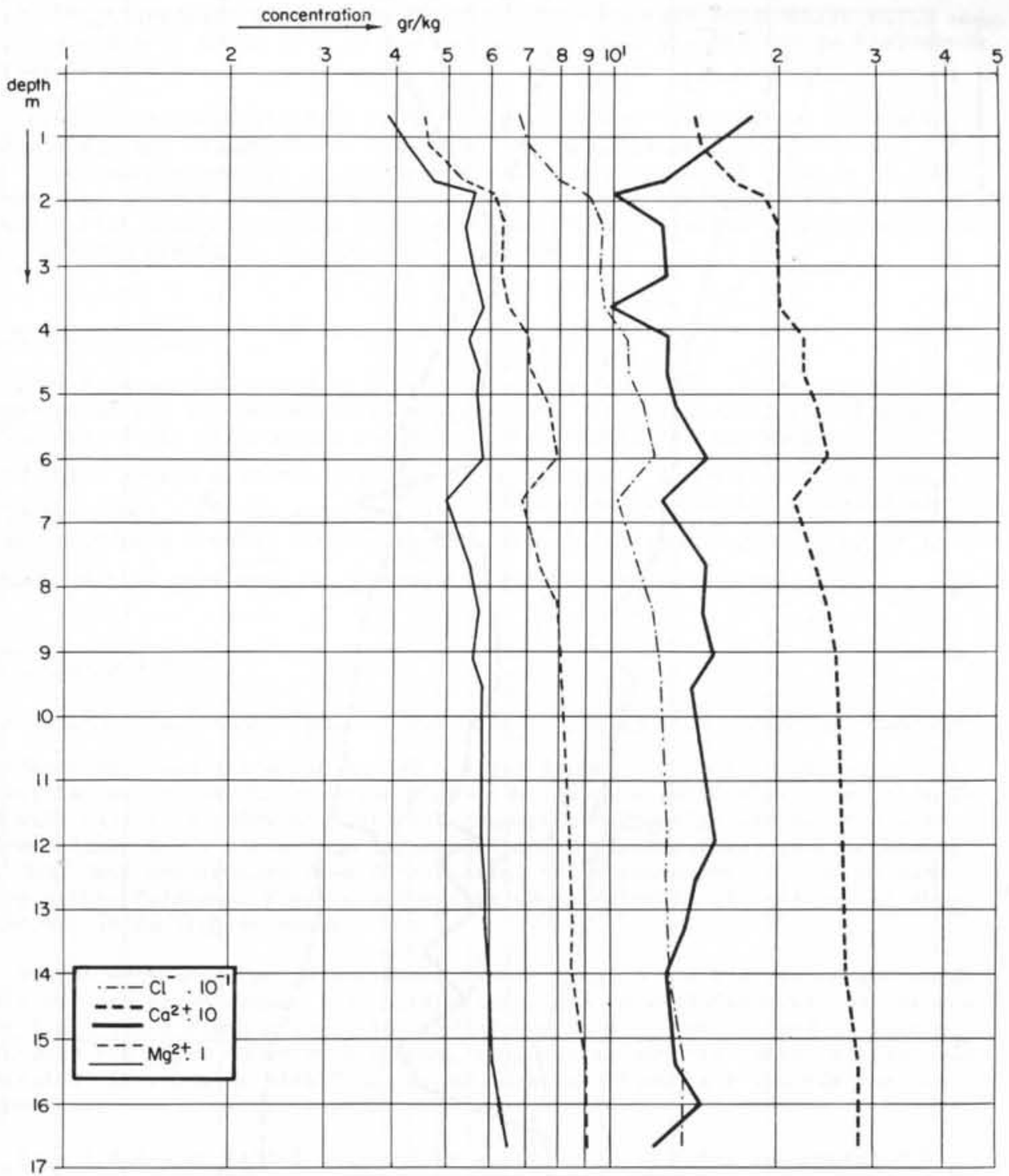

WELL D

\section{ニニニニ- Represent the $\mathrm{Ca}^{2+}$ and $\mathrm{Mg}^{2+}$ concentrations wich would exist if only concentration of the water had taken place --- without $\mathrm{Ca}^{2+}$ or $\mathrm{Mg}^{2+}$ loss \\ Actual concentrations}

Fig. 2D. Comparison of concentrations of $\mathrm{Ca}^{2+}$ and $\mathrm{Mg}^{2+}$ with the $\mathrm{Cl}^{-}$-concentration in the interstitial water as a function of depth 


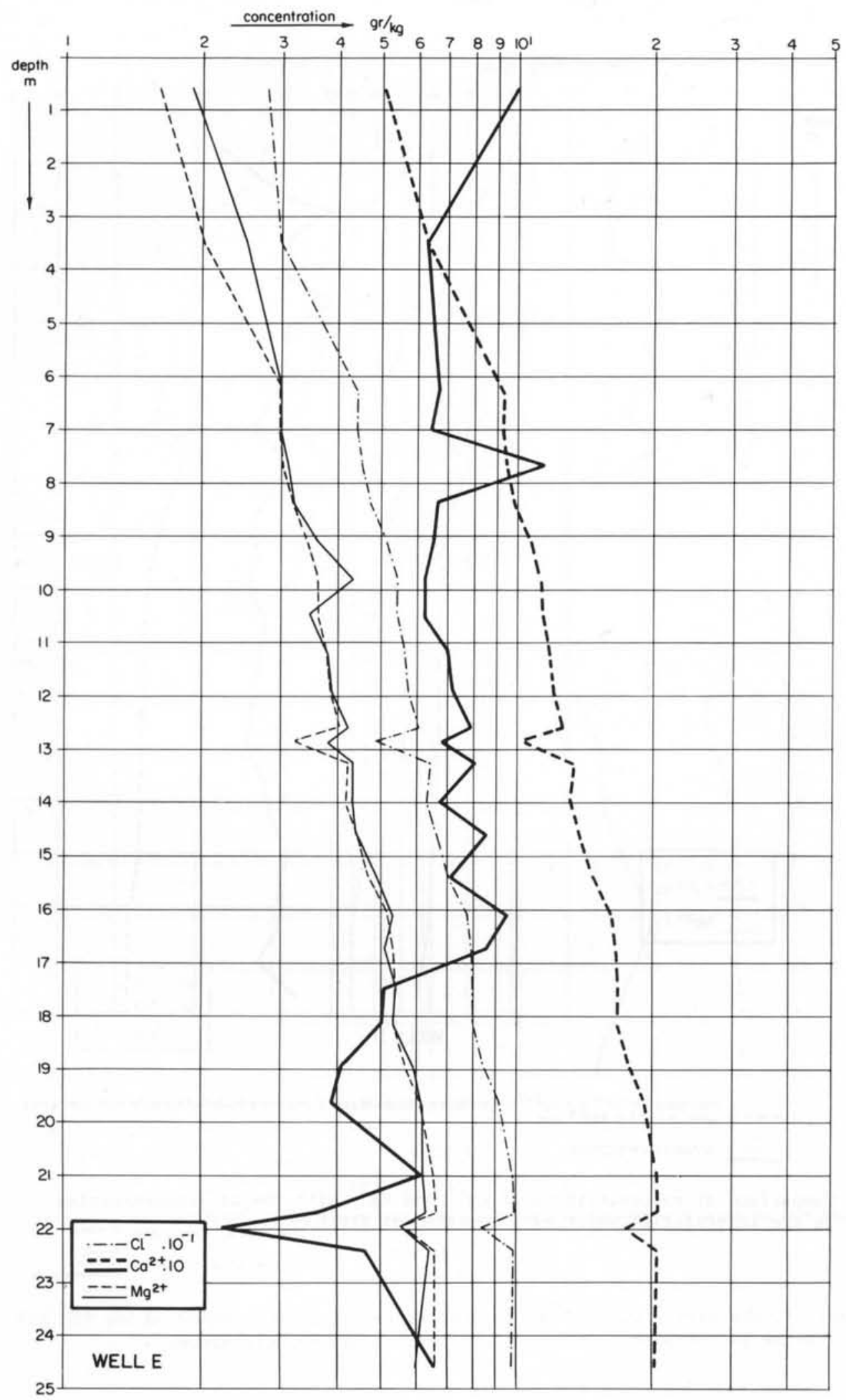

Legend to Fig. 2E on the following page 
of carbonate or bicarbonate was not attempted as the carbonate/bicarbonate ratio and the absolute amounts of these ions in the cores could have changed due to biological action during transport.

Chloride was determined by automatic potentiometric titration with $\mathrm{AgNO}_{3}$. The sum of calcium and magnesium was determined by EDTA titration. Calcium was determined by flame-photometry, as the complexometric titration of calcium in the presence of large amounts of magnesium gives rise to large systematic errors. Sulphate was determined with lead nitrate in an acetone-water mixture after chloride removal and an ion exchange procedure to replace all cations by $\mathrm{H}^{+}$.

\section{Analysis of the sediment}

Some data were obtained by X-ray diffraction analysis. The figures given for the amounts of the various minerals present have a total analytical error of $\pm 15 \%$ (relative). X-ray diffraction was also used to determine the amount of $\mathrm{CaCO}_{3}$ in dolomite which showed that all analyzed Eocene dolomite in Qatar has the composition $\left(\mathrm{Ca}_{0.50 \pm 0.005} \cdot \mathrm{Mg}_{0.50 \pm 0.005} \mathrm{CO}_{3}\right)$, whereas Recent dolomite contains more $\mathrm{Ca}$, with up to 57 mole $\% \mathrm{CaCO}_{3}$ (Illing et al., 1965). The amount of $\mathrm{Ca}$ present in the dolomite has thus been used to distinguish Eocene from Recent dolomite.

\section{RESULTS AND DISCUSSION}

\section{Chlorinity and density distribution of the interstitial water as evidence of reflux}

Water analyses are given in Table I and Figures 2a to e. Chlorinities of the interstitial waters are high, especially in wells A, B and C where the water is saturated with halite. A chlorinity profile constructed from the sample points is presented in figure 3. It shows that the distribution of chlorinity is essentially different from that constructed from interstitial water measurements made by van der Poel on Sabkha Faishakh, W Qatar, a locality where dolomite is forming. It shows dense water overlying lighter water.

In the permeable Umm Said Sabkha, between we11 B and the sea, heavy water is overlaid by less dense water, a situation which can be explained best by the reflux theory: sea water flowing in during occasional marine flooding and by lateral seepage through the upper layer of sediment, evaporates from the sabkha surface and is concentrated. It tends to sink into the sediment and flow back towards the sea through the deeper parts of the sabkha.

In a tidal-flat filled with saline water which is being concentrated by surface evaporation, the water lost by evaporation will generally be compensated by inflow of adjacent sea water. As a result water density increases landwards and the free water level becomes somewhat lower. One can envisage, in the absence of flow, a horizontal level within the sabkha above which the weights of the water columns are equal everywhere, or, in other words, a level at which a line of constant hydrostatic pressure is horizontal. At this level no horizontal flow can take place. Above this level, horizontal flow, once begun, will be landwards; below this leve1 the flow will be seawards if no permeability barriers are present. Figure 4 demonstrates the conditions under which reflux is theoretically possible.

Fig. 2E. COMPARISON OF CONCENTRATIONS OF $\mathrm{Ca}^{2+}$ AND $\mathrm{Mg}^{2+}$ WITH THE $\mathrm{CL}^{-}$-CONCENTRATION IN THE INTERSTITIAL WATER AS A FUNCTION OF DEPTH

ニーニーニ゙ニ Represent the $\mathrm{Ca}^{2+}$ and $\mathrm{Mg}^{2+}$ concentrations which would exist if only concentration of the water had taken place without $\mathrm{Ca}^{2+}$ or $\mathrm{Mg}^{2+}$ loss 


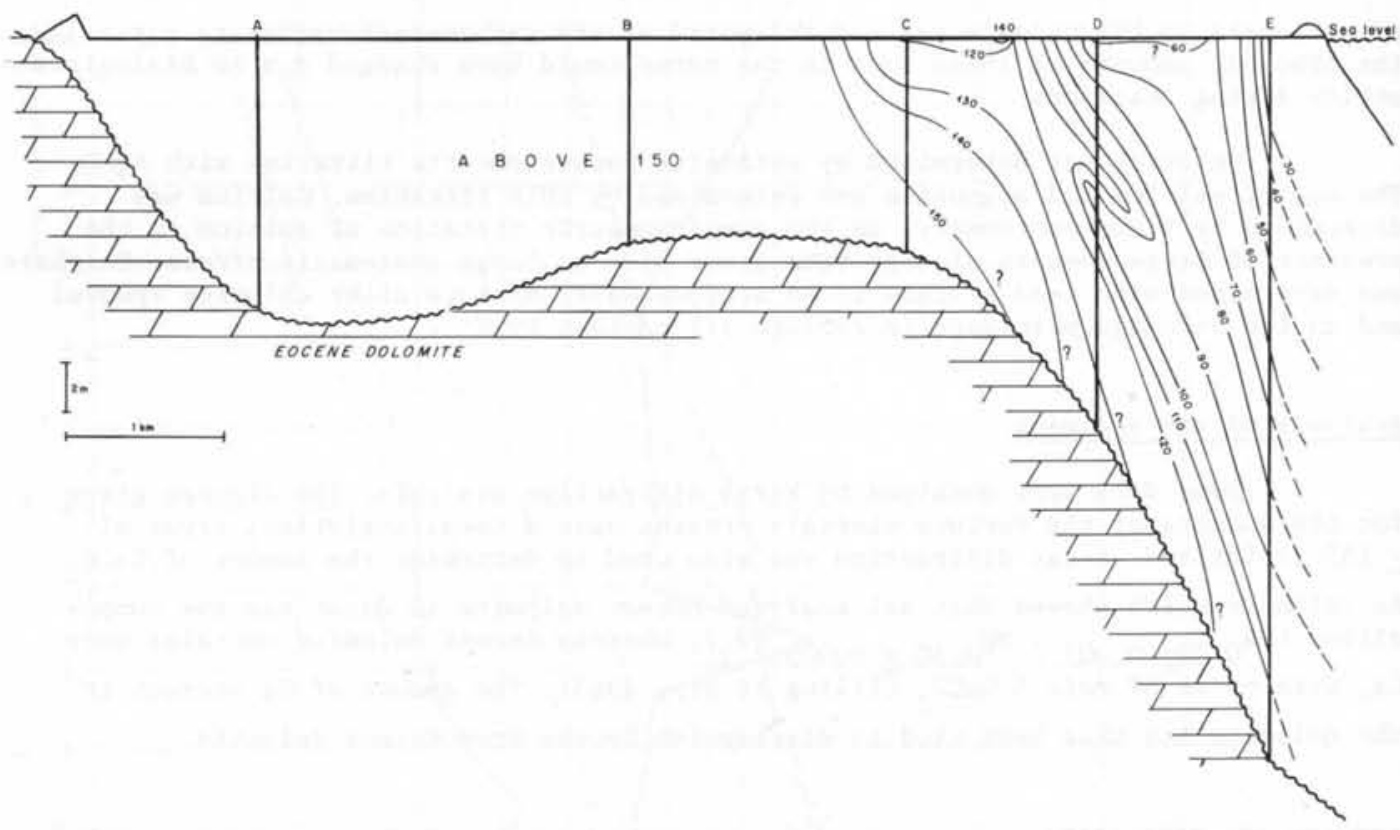

Fig. 3. Isochlorinity lines (in parts per thousand) of the interstitial water in the sabkha

In the Umm Said sabkha the free water level was not measured exactly in the field, but was found to vary very little: it was about $50 \mathrm{~cm}$ below the horizontal sabkha surface everywhere. Assuming a linear drop of $50 \mathrm{~cm}$ in the water level from wel1 $\mathrm{E}$ to well $\mathrm{B}$ (which is probably excessive) and assuming vertical flow resistance to be negligible, one can readily calculate the hydrostatic pressures at various depths. In Table 2 the hydrostatic pressures at $8 \mathrm{~m}$ and (where possible) at $16 \mathrm{~m}$ depth are 1isted. It is clear that under the assumed conditions the horizontal line of constant pressure is present above $8 \mathrm{~m}$ in the Umm Said sabkha. One can calculate the rate of flow in the sediment under influence of the hydrostatic pressure differences, using Darcy's law. For instance, the rate of flow between we11 B and C at $8 \mathrm{~m}$ depth becomes:

$$
\frac{\Delta \mathrm{p} \cdot \mathrm{k}}{\eta \cdot \mathrm{l}}=\frac{0.154 \times 20}{2 \times 1.77 \times 10^{5}}=8.7 \times 10^{-6} \mathrm{~cm} / \mathrm{sec}=274 \mathrm{~m} / \text { year }
$$

using the hydrostatic pressure difference $\Delta \mathrm{p}$ at $8 \mathrm{~m}=0.154 \mathrm{~kg} / \mathrm{cm}^{2}$.

$$
\begin{aligned}
& \text { the viscosity } \eta \text { of the brine }=2 \text { centipoise } \\
& \text { a (uniform) permeability } k \text { of the sediment }=20 \text { darcies } \\
& \text { the distance } l \text { between we11 } \mathrm{C} \text { and } \mathrm{B}=1770 \mathrm{~m} \text {. }
\end{aligned}
$$

In Table 3 a number of possible flow rates between the wells, under the influence of hydrostatic pressures on $1 y$, are listed for uniform permeabilities of 1 and 20 darcies respectively. In the coarse, upper parts of the sabkha permeabilities of 10 darcies are likely, so that rates of seaward flow of a few tens of metres per year are possib1e. If the drop in water level going from $\mathrm{E}$ to $\mathrm{B}$ is less than $50 \mathrm{~cm}$, the calculated flow rates will be higher.

These calculations suggest therefore that a seaward flow of hypersaline water exists in the deeper part of the sabkha between wells C and E. However, no significant circulation seems to take place in the most inland part of the tidal-flat between well A and $\mathrm{C}$, as only minor chlorinity or density gradients were recorded. 


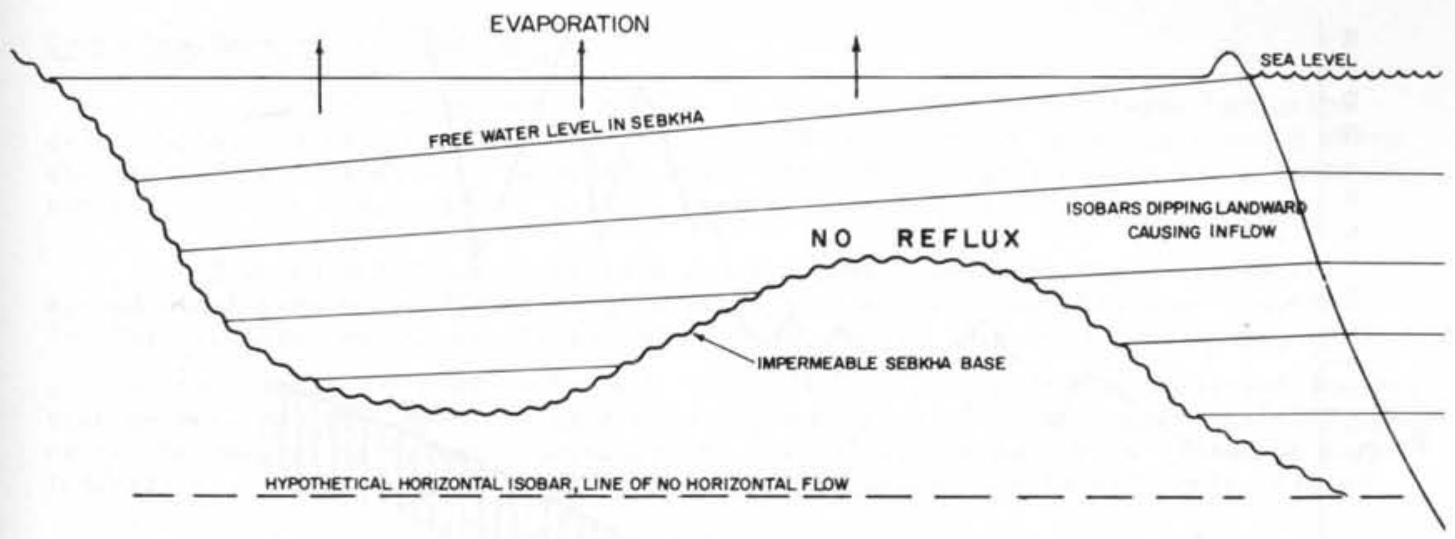

Fig. A

NO REFLUX IN SEBKHA, INFLUX BALANCES EVAPORATION
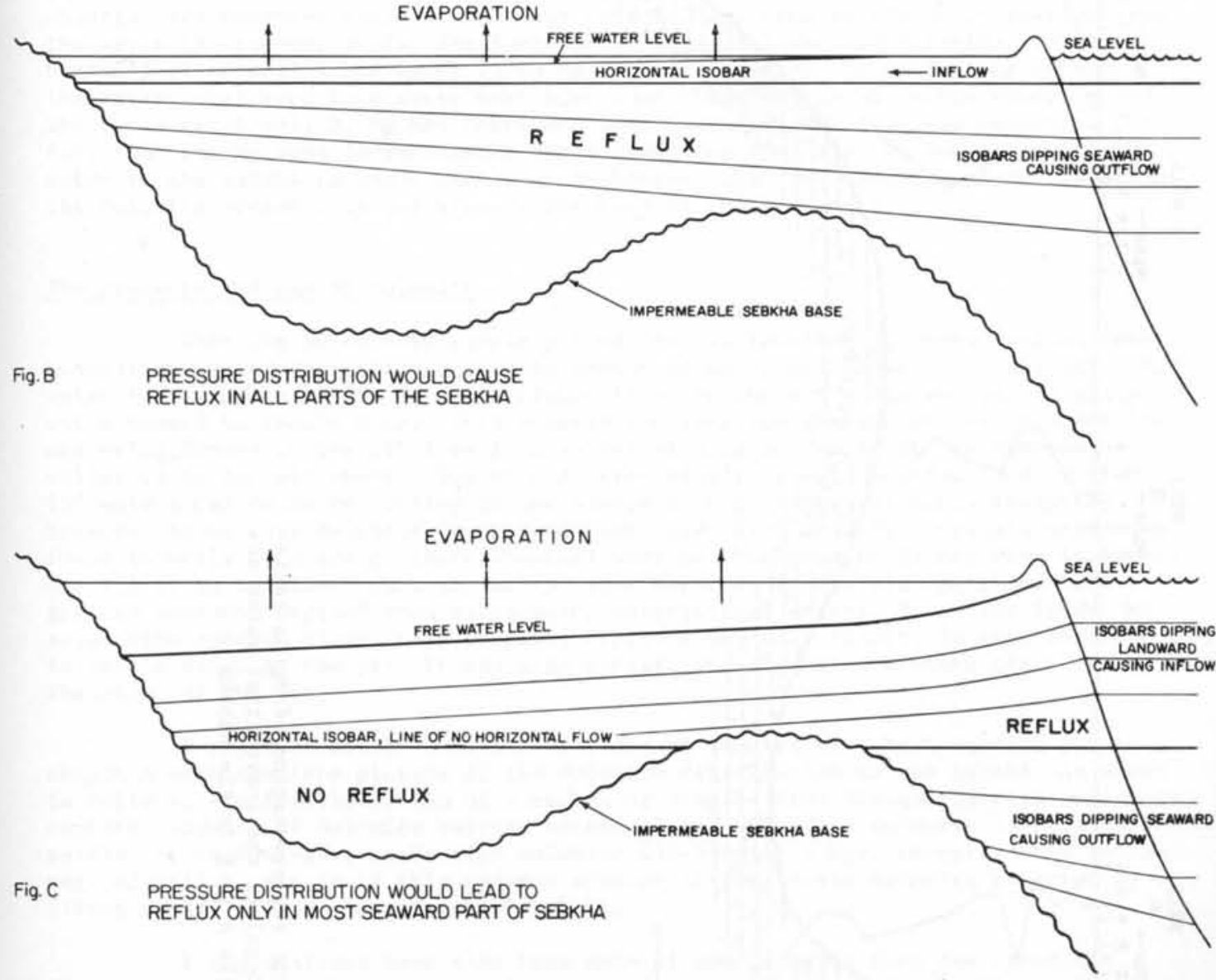

Horizontal flow will take place in the direction of the lower pressure

Fig. 4. Possible hydrostatic pressure distributions in stationary model of Umm Said Sabkha 


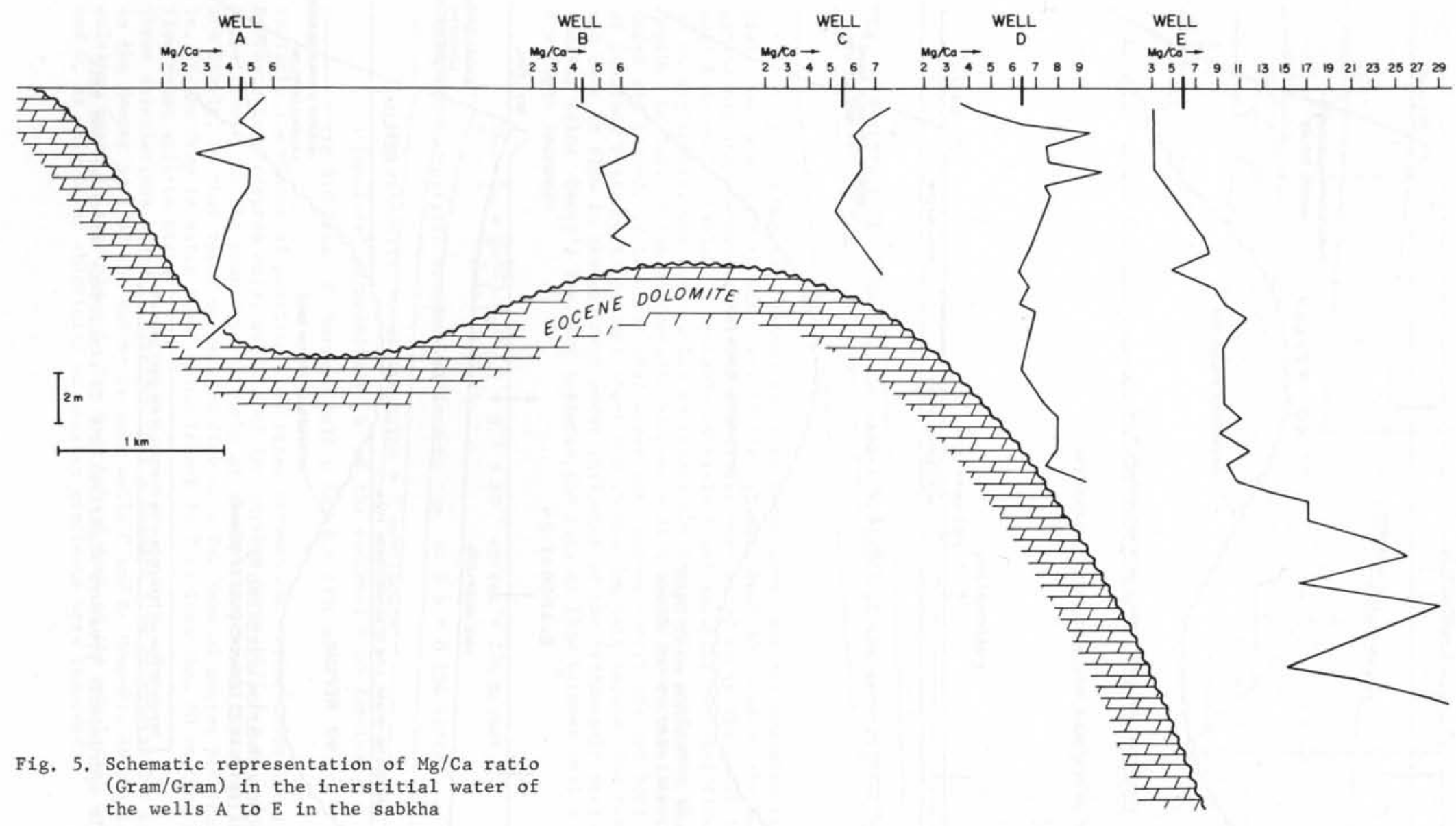


Concentrations of $\mathrm{Ca}^{++}$and $\mathrm{Mg}^{++}$

A plot of the $\mathrm{Mg} / \mathrm{Ca}$ ratio (Fig. 5) shows that a rather large variation exists along the traverse. The lowest values are encountered in we $11 \mathrm{~s} A$ and $\mathrm{B}$ where the highest salinities were recorded, while the highest $\mathrm{Mg} / \mathrm{Ca}$ ratios are present in the water in the lower part of well E, nearest the present coast.

High chlorinities in wells A and B probably indicate that this water has already lost gypsum (or anhydrite); in wells A, B and C gypsum has been observed (by Shinn). Although the precipitation of $\mathrm{CaSO}_{4}$ should have resulted in $\mathrm{high} \mathrm{Mg} / \mathrm{Ca}$ ratios, this ratio is found to be low. This must have been caused by dolomite formation because no other Mg-salts have been found by X-ray diffraction analysis. Because the process of dolomite formation is very slow, the low $\mathrm{Mg} / \mathrm{Ca}$ ratios measured indicate that water supply to this inland part of the sabkha is extremely limited.

In figures $2 \mathrm{~A}-2 \mathrm{E}$ the dotted lines give the amount of $\mathrm{Ca}$ and $\mathrm{Mg}$ which would be present if the sea water had been concentrated without any $\mathrm{Ca}$ and $\mathrm{Mg} 10$ ss by precipitation of $\mathrm{CaCO}_{3}$, gypsum or dolomite. It is clear that in all wells the waters must have lost a considerable amount of $\mathrm{Ca}^{++}$as gypsum, calcium carbonate or dolomite. The trend is reversed in the top part of we11 $\mathrm{A}$. In view of the very high chlorinities measured there it is clear that the observed halite precipitation from the water is responsible for the increase in the $\mathrm{Mg} / \mathrm{Cl}$ and $\mathrm{Ca} / \mathrm{Cl} \mathrm{ratios}$. In the bottom part of well $\mathrm{A}$ the $\mathrm{Ca} / \mathrm{Cl}$ ratio is high in spite of the $\mathrm{Ca}$ loss as gypsum, indicating that even this water must have lost chloride. In all wells except $\mathrm{E}$ and the top part of well D, Mg has therefore been lost from solution, as dolomite. The fact that the Mg loss is noticeable again indicates that the residence time of the water in the sabkha is about the same, or longer, than the time necessary to form the dolomite present, as was already observed in wells $A$ and $B$.

\section{The presence and age of dolomite}

When the $50 \mathrm{~cm}$ deep sample pit was dug at location B, Shinn (verbal communication) noted that, after a certain amount of water had flowed into the pit, this water turned milky. While water continued to enter the pit a rim around the milky water seemed to remain clear. This observation gave the impression that a precipitate was being formed in the pit itself. Analysis of a large sample of the suspension collected in the pit showed that it consisted mainly of well-ordered, and Ca-rich ( $55 \mathrm{~mole} \% \mathrm{Ca}$ ) dolomite. Dating of the sample by E.L. Martin of She11 Research, Houston showed this dolomite to be 5000 years old. Fine dolomite crystals were also found in wells A, B and C. (More chemical work on this problem is reported in Appendix A.) It is concluded that the milky water observed in the pit contained fine grained sediment derived from surrounding interstitial waters. In a thin layer the suspension appears clear; this probably explains why no turbidity is seen when there is little water in the pit. It may also explain why the water appears clear around the edges of the pit.

X-ray diffraction analyses of sediment samples have been carried out to obtain a more complete picture of the dolomite distribution in the sabkha. As shown in Table 4, the fraction $<16 \mu$ of a number of samples from the quartz-rich sediments contains amounts of dolomite varying between 5 and $40 \%$. This dolomite is present partly, or exclusively, as Ca-rich dolomite ( $53-55 \mathrm{~mole} \% \mathrm{Ca}$ ), except in the bottom part of well E, and is in this respect similar to the Recent dolomite reported by Illing et al. (1965), from Sabkha Faishakh.

$\mathrm{X}$-ray analyses have also been made of some samples from the carbonate "Unit 4" present in the transgressive part of the sabkha (see Shinn, Fig. 5 in this volume), the results of which are presented in Table 5. All dolomite in the fraction $<16 \mu$ of these samples is Ca-rich, but the amounts found are small. The coarser fraction has larger amounts of dolomite, but this is probably derived from adjacent Eocene dolomites as the composition is $\mathrm{Ca}_{0.50} \mathrm{Mg}_{0.50} \mathrm{CO}_{3}$. Furthermore, these crystals 
are too large to have formed in 5000 years, the approximate age of the sabkha.

It is concluded that Recent dolomite occurs in rather small amounts all over the sabkha. In the quartz-rich sediment the highest concentrations of dolomite are found in we11 B where the dolomite has a ${ }^{14} \mathrm{C}$ age of 5000 years. The concentration of dolomite in the carbonate layers varies erratically.

\section{Role of reflux in the distribution of dolomite}

The amount of $\mathrm{Mg}^{++}$ions necessary to form the dolomite present in we11s A, $B$ and $C$ has been estimated. The amount of the fraction $<16 \mu$ in this sediment is approximately $1 \%$ (average of 15 determinations). The percentage of Recent dolomite in this fraction averages $20 \%$, so that $0.2 \%$ of the sediment is Recent dolomite. Assuming a porosity of $30 \%$ there exists per $1000 \mathrm{~cm}^{3}$ of sediment $700 \mathrm{~cm}^{3}$ or about $2 \mathrm{~kg}$ of solid including $4 \mathrm{~g}$ of dolomite. To form this dolomite from $300 \mathrm{~cm}^{3}$ of interstitial water requires $4 \times 0.12 \times \frac{1000}{300}=1.6 \mathrm{~g} \mathrm{Mg}^{++}$per 1itre of water. In the wells $\mathrm{A}, \mathrm{B}, \mathrm{C}$ and even in the bottom part of we11 D, the amount of $\mathrm{Mg}^{++}$actually lost from the interstitial waters is of the same order (see Fig. 2), so that extra water supply is not necessary to account for the dolomite found in this part of the sabkha.

As the reflux process was shown to be inactive in the inland part of the sabkha (the part west of well c), the dolomite in that area seemingly has not been formed via a reflux process.

The area where refluxing seems to be active has relatively less dolomite than the inland part of the sabkha and, at least in well $\mathrm{C}$ and the bottom part of we11 D, it has been demonstrated that a reflux system is not necessary to explain the limited amount of dolomite present. In the quartz sediment in the lowest part of well E no Recent dolomite has formed, possibly because this sediment is too young to allow time for dolomitization.

Dolomite present in the carbonate layers in the sabkha has to be disregarded as proof of the effectiveness of reflux for dolomitization; stromatolites and mudcracks have been found in this layer indicating that it could have formed as a supratidal crust.

In summary, the refluxing of hypersaline waters, although a potential dolomitizing process, is not necessary to explain the distribution and limited amounts of dolomite in the Umm Said sabkha.

\section{CONCLUSIONS}

A study of the dominantly quartz sand sabkha at Umm Said, SE Qatar has revealed that the landward part of the sabkha is filled with brine saturated, or almost saturated, with halite. This brine is probably almost stagnant, and has 10 st $\mathrm{Mg}^{++}$. This loss of $\mathrm{Mg}^{++}$can fully account for the small amount of Recent dolomite found in the sediment, which also contains sufficient fine grained calcium carbonate to act as a carbonate source for the dolomite. Dolomitization is probably very slow in this part of the sabkha and is seemingly not the result of a refluxing system.

The demonstration of Recent dolomite at Umm Said is admittedly of secondary interest in view of earlier discoveries of this mineral around the Persian Gulf, and elsewhere (Florida, Bahamas, Australia); the fact, however, that research has demonstrated a reflux mechanism potentially capable of effecting wisespread dolomitization, is regarded as significant. 
$\underline{\text { Table I }}$

Analyses of interstitial water from cores

We11 A

\begin{tabular}{|rcccc|}
\hline No. & Depth, m & $\mathrm{Clg} / \mathrm{kg}$ & $\mathrm{Ca} \mathrm{g} / \mathrm{kg}$ & $\mathrm{Mg} \mathrm{g} / \mathrm{kg}$ \\
\hline 1 & $0.62-0.72$ & 157.94 & 4.346 & 13.603 \\
2 & $1.36-1.46$ & 149.30 & 4.375 & 11.287 \\
3 & $2.03-2.13$ & 165.39 & 4.288 & - \\
4 & $2.76-2.86$ & - & -980 \\
5 & $3.40-3.50$ & 147.81 & 4.278 & 12.364 \\
6 & $4.15-4.25$ & 161.68 & 3.440 & 9.720 \\
7 & $4.82-4.92$ & 159.27 & 3.064 & -121 \\
8 & $5.51-5.61$ & - & 3.219 & 7.281 \\
9 & $6.23-6.33$ & 164.53 & 3.205 & 6.859 \\
10 & $6.94-7.04$ & 160.18 & 3.366 & 6.888 \\
11 & $7.63-7.73$ & 149.69 & 3.459 & 6.954 \\
12 & $8.00-8.10$ & 151.65 & 3.213 & 7.808 \\
13 & $8.66-8.76$ & 160.55 & 3.048 & 7.707 \\
14 & $9.61-9.71$ & 161.09 & 3.546 & 7.707 \\
15 & $10.43-10.53$ & 158.48 & - & - \\
16 & $11.14-11.24$ & - & & \\
\hline
\end{tabular}

$\underline{\text { We11 B }}$

\begin{tabular}{|c|c|c|c|c|}
\hline No. & Depth, m & $\mathrm{Cl} \mathrm{g} / \mathrm{kg}$ & $\mathrm{Ca} \mathrm{g} / \mathrm{kg}$ & $\mathrm{Mg} \mathrm{g} / \mathrm{kg}$ \\
\hline 1 & $0.63-0.73$ & 159.94 & 2.672 & 6.338 \\
\hline 2 & $2.04-2.14$ & 156.45 & 1.565 & 6.262 \\
\hline 3 & $2.70-2.80$ & 157.00 & 1.633 & 6.364 \\
\hline 4 & $3.36-3.46$ & 157.56 & 2.111 & 6.377 \\
\hline 5 & $4.17-4.27$ & 156.95 & 2.032 & 6.465 \\
\hline 6 & $4.87-4.97$ & 153.42 & 1.925 & 6.525 \\
\hline 7 & $5.59-5.69$ & 152.77 & 1.728 & 6.460 \\
\hline 8 & $6.28-6.38$ & 155.19 & 1.977 & 6.612 \\
\hline 9 & $6.65-6.78$ & 150.60 & 1.744 & 6.611 \\
\hline
\end{tabular}

$\underline{\text { We11 C }}$

\begin{tabular}{|rllll|}
\hline No. & Depth, m & C1 g/kg & Ca g/kg & Mg g/kg \\
\hline 1 & $0.63-0.73$ & 124.98 & 1.268 & 5.810 \\
2 & $1.22-1.33$ & 122.79 & 1.379 & 5.569 \\
3 & $1.84-1.94$ & 129.10 & 1.488 & 5.457 \\
4 & $2.51-2.61$ & 135.79 & 1.495 & 5.797 \\
5 & $3.35-3.45$ & 145.04 & 1.566 & 6.046 \\
6 & $4.04-4.14$ & 145.84 & 1.726 & 6.070 \\
7 & $4.76-4.86$ & 147.40 & 4.281 & 4.528 \\
8 & $5.10-5.20$ & 143.91 & 1.972 & 6.147 \\
9 & $7.35-7.45$ & 150.16 & 1.532 & 6.367 \\
10 & $7.98-8.08$ & 146.41 & 1.475 & 6.419 \\
\hline
\end{tabular}


We11 D

\begin{tabular}{|rrrll|}
\hline No. & \multicolumn{1}{l}{ Depth, m } & C1 g/kg & Ca g/gk & Mg g/kg \\
\hline 1 & $0.66-0.76$ & 66.943 & 1.780 & 3.948 \\
2 & $1.11-1.19$ & 69.312 & 1.504 & 4.176 \\
3 & $1.61-1.71$ & 77.745 & 1.241 & 4.739 \\
4 & $1.86-1.96$ & 90.002 & 0.993 & 5.634 \\
5 & $2.37-2.47$ & 95.014 & 1.215 & 5.424 \\
6 & $3.08-3.18$ & 94.323 & 1.230 & 5.603 \\
7 & $3.59-3.69$ & 95.795 & 0.970 & 5.770 \\
8 & $4.08-4.18$ & 104.96 & 1.245 & 5.518 \\
9 & $4.61-4.71$ & 106.55 & 1.236 & 5.655 \\
10 & $5.15-5.25$ & 113.03 & 1.295 & 5.745 \\
11 & $5.92-6.02$ & 119.03 & 1.476 & 5.803 \\
12 & $6.59-6.69$ & 102.00 & 1.218 & 4.986 \\
13 & $7.67-7.77$ & 111.15 & 1.475 & 5.492 \\
14 & $8.34-8.44$ & 118.75 & 1.455 & 5.742 \\
15 & $9.06-9.16$ & 121.87 & 1.515 & 5.569 \\
16 & $9.49-9.59$ & 122.53 & 1.402 & 5.756 \\
17 & $11.85-11.95$ & 127.29 & 1.538 & 5.777 \\
18 & $12.54-23.64$ & 124.83 & 1.422 & 5.821 \\
19 & $13.23-13.33$ & 126.06 & 1.362 & 5.857 \\
20 & $13.95-14.05$ & 126.64 & 1.259 & 5.985 \\
21 & $15.35-15.45$ & 134.99 & 1.307 & 6.142 \\
22 & $15.97-16.07$ & 133.90 & 1.437 & 6.290 \\
23 & $16.62-16.72$ & 133.72 & 1.201 & 6.542 \\
\hline
\end{tabular}

We11 E

\begin{tabular}{|c|c|c|c|c|c|}
\hline No. & Depth, & , m & $\mathrm{Cl} \mathrm{g} / \mathrm{kg}$ & $\mathrm{Ca} \mathrm{mg/kg}$ & $\mathrm{Mg} \mathrm{mg} / \mathrm{kg}$ \\
\hline 1 & 0.52 & $-\quad 0.62$ & 28.107 & 982.3 & 1896 \\
\hline 5 & 3.44 & $-\quad 3.54$ & 30.006 & 633.5 & 2544 \\
\hline 9 & 6.22 & -6.32 & 44.087 & 671.0 & 3007 \\
\hline 10 & 6.94 & -7.04 & 44.052 & 643.1 & 3024 \\
\hline 11 & 7.66 & $-\quad 7.76$ & 44.546 & 1141.5 & 3108 \\
\hline 12 & 8.34 & -8.44 & 46.609 & 660.4 & 3187 \\
\hline 13 & 9.05 & $-\quad 9.15$ & 51.409 & 651.0 & 3560 \\
\hline 14 & 9.75 & $-\quad 9.85$ & 54.011 & 618.0 & 4311 \\
\hline 15 & 10.41 & -10.51 & 53.698 & 624.6 & 3515 \\
\hline 16 & 11.09 & -11.19 & 56.070 & 700.9 & 3782 \\
\hline 17 & 11.84 & -11.94 & 57.030 & 723.5 & 3899 \\
\hline 18 & 12.53 & -12.63 & 60.185 & 779.2 & 4198 \\
\hline 19 & 13.21 & -13.31 & 63.651 & 803.3 & 4346 \\
\hline 20 & $13.93-$ & -14.03 & 63.415 & 665.9 & 4267 \\
\hline 21 & 14.54 & -14.64 & 65.606 & 846.6 & 4372 \\
\hline 22 & $15.34-$ & -15.44 & 70.367 & 712.8 & 4866 \\
\hline 23 & $16.06=$ & -16.16 & 76.855 & 945.1 & 5258 \\
\hline 24 & $16.69-$ & -16.79 & 78.245 & 853.0 & 5112 \\
\hline 25 & $17.47-$ & -17.57 & 78.943 & 514.1 & 5356 \\
\hline 26 & $18.11-$ & -18.21 & 80.251 & 505.6 & 5302 \\
\hline 27 & $18.84-$ & -18.94 & 83.784 & 413.5 & 5889 \\
\hline 28 & $19.54-$ & -19.64 & 92.725 & 387.9 & 6157 \\
\hline 29 & $19.86-$ & -19.91 & 38.367 & 478.9 & 2362 \\
\hline 30 & 20.95 & -21.05 & 97.827 & 618.6 & 6165 \\
\hline 31 & $21.67-$ & -21.77 & 98.556 & 359.5 & 6349 \\
\hline 32 & $22.37=$ & -22.47 & 97.636 & 464.9 & 6360 \\
\hline
\end{tabular}




$\begin{array}{ll}22.90-23.00 & 31.587 \\ 24.49-24.59 & 96.887 \\ 25.02-25.12 & 72.790 \\ 25.86-25.90 & 105.68 \\ 26.54-26.64 & 113.99 \\ 27.25-27.35 & 113.363 \\ 27.74-27.84 & 109.26 \\ 28.66-28.76 & 119.77 \\ 29.16-29.26 & 116.43\end{array}$

400.7

656.6

363.2

366.2

\section{Table 2}

Hydrostatic pressure in the wells along the traverse (difference in water level between well $\mathrm{E}$ and $\mathrm{B} ; 50 \mathrm{~cm}$ )

\begin{tabular}{|c|c|c|c|}
\hline We11 & Pressure at $8 \mathrm{~m}$ & Pressure at $16 \mathrm{~m}$ & Distance \\
\hline B & $1.10 \mathrm{~kg} / \mathrm{cm}^{2}$ & - & $\mathrm{BC}=1786 \mathrm{~m}$ \\
\hline C & 0.98 & - & $"$ \\
\hline D & 0.95 & $1.88 \mathrm{~kg} / \mathrm{cm}^{2}$ & $\mathrm{CD}=1203 \mathrm{~m}$ \\
\hline E & 0.89 & $1.76 "$ & $\mathrm{DE}=1054 \mathrm{~mm}$ \\
\hline
\end{tabular}

\section{$\underline{\text { Table } 3}$}

Possible water flow rates in metres per year at depths of 8 and 16 m for various permeabilities $\left.{ }^{*}\right)$

Permeability: 1 darcy

Flow between $B$ and C

$$
\text { at } 8 \mathrm{~m} \text { depth }
$$

$+11$

$+4$

" between C and D at $8 \mathrm{~m}$ depth

" between D and E
20 darcies
$+8.5$
$+17.2$
at $8 \mathrm{~m}$ depth
at 16 mdepth
$+170$

*) Seaward flow direction is taken as positive 
Table 4

$\underline{X-r a y}$ diffraction analysis of fraction $<16 \mu$ of samples from the upper quartz-rich part of the sabkha*)

\begin{tabular}{|lr|c|c|c|c|c|c|}
\hline & & Aragonite & Calcite & Mg-Calcite & Dolomite & $\begin{array}{l}\% \text { CaCO } \\
\text { in do1. }\end{array}$ & $\begin{array}{c}\text { Other minerals } \\
\text { (Quartz, felds. }\end{array}$ \\
\hline A1 & $0.68-0.76 \mathrm{~m}$ & 30 & 15 & 5 & 20 & 54 & 30 \\
A3 & $1.61-1.71 \mathrm{~m}$ & 40 & 15 & 20 & 15 & $51 ; 54$ & 10 \\
A5 & $2.37-2.47 \mathrm{~m}$ & 40 & 10 & 20 & 15 & $50 ; 54$ & 15 \\
B1 & $0.63-0.73 \mathrm{~m}$ & 35 & 10 & 5 & 40 & 55 & 10 \\
B3 & $2.70-2.80 \mathrm{~m}$ & 40 & 10 & 10 & 30 & 54 & 10 \\
C2 & $1.22-1.32 \mathrm{~m}$ & 40 & 10 & 15 & 20 & 55 & 15 \\
C4 & $2.51-2.61 \mathrm{~m}$ & 25 & 35 & - & 15 & 55 & 25 \\
C6 & $4.04-4.14 \mathrm{~m}$ & 30 & 20 & 15 & 15 & 55 & 20 \\
D2 & $1.36-1.46 \mathrm{~m}$ & 30 & 25 & 15 & 15 & 53 & 30 \\
D8 & $5.51-5.61 \mathrm{~m}$ & 40 & 20 & 10 & 10 & $50 ; 55$ & 20 \\
D15 & $10.43-10.53 \mathrm{~m}$ & 25 & 20 & 5 & 10 & 53 & 50 \\
E1 & $0.52-0.62 \mathrm{~m}$ & 50 & 10 & - & 5 & $50 ; 53$ & 35 \\
E10 & $6.94-7.04 \mathrm{~m}$ & 30 & 20 & 20 & 15 & $50 ; 53$ & 15 \\
E17 & $11.84-11.94 \mathrm{~m}$ & 50 & 10 & - & 5 & 50 & 35 \\
E27 & $18.84-18.94 \mathrm{~m}$ & 10 & 25 & 10 & 5 & 50 & 50 \\
\hline
\end{tabular}

*) For the dolomite the amount of $\mathrm{CaCO}_{3}$ in the lattice is also included. When two figures are listed two separate dolomite peaks could be distinguished on the $\mathrm{X}$-ray diffraction pattern. The dolomite containing 50 mole $\% \mathrm{CaCO}_{3}$ is probably of Eocene age.

$\underline{\text { Table } 5}$

Amount of dolomite as found by semi-quantitative X-ray diffraction of samples taken from the carbonate layers present in the various we1ls

\begin{tabular}{|c|c|c|c|c|c|}
\hline \multirow{2}{*}{$\begin{array}{c}\text { Sample } \\
\text { we11 }\end{array}$} & Depth & \multicolumn{2}{|c|}{ Fraction $<16 \mu$} & \multicolumn{2}{|c|}{ Fraction $16-53 \mu$} \\
\cline { 3 - 6 } & & $\%$ Dolomite & $\% \mathrm{CaCO}_{3}$ in do1. & \% Dolomite & $\% \mathrm{CaCO}_{3}$ in do1. \\
\hline A & $3.69-3.72 \mathrm{~m}$ & 5 & 55 & - & - \\
B & $6.40-6.43 \mathrm{~m}$ & 5 & 55 & 10 & 50 \\
C & $6.00-6.03 \mathrm{~m}$ & 15 & 55 & 5 & 50 \\
D & $13.40-13.43 \mathrm{~m}$ & 5 & 54 & 20 & 50 \\
E & $24.63-24.66 \mathrm{~m}$ & 15 & 55 & 25 & 50 \\
\hline
\end{tabular}




\section{POSSIBILITY OF RAPID DOLOMITE FORMATION: SOME EXPERIMENTAL EVIDENCE}

E. A. Shinn has observed that water flowing into a pit near well B suddenly turned milky. The milkiness appeared to be due to significant amounts of (ordered) dolomite in the water. Following this observation a number of experiments have been carried out to test the possibility of instant ordered dolomite formation. It was presumed that $t_{3}$ if dolomite formed in a few seconds by some inorganic mechanism*), this process could be repeated in the laboratory.

Milky water sample ES 129 from a pit dug near well B was filtered and $\mathrm{Ca}^{++}$ and $\mathrm{Mg}^{++}$were added in amounts equivalent to 2,5 and 10 grams of dolomite formed per litre of water. The water was then flushed with $\left.\mathrm{CO}_{2}{ }^{*}\right)$. Bicarbonate was added to the rather acid solutions, again in amounts equivalent to 2,5 and 10 grams of dolomite and the solutions were allowed to lose their $\mathrm{CO}_{2}$ slowly to the air so that precipitation could occur. The precipitates which formed after some hours standing were filtered off and analyzed by X-ray diffraction (see table A-1). No immediate dolomite formation occurred and only a mixture of aragonite and $\mathrm{Mg}-\mathrm{calcite}$ was found. The water from which the carbonate minerals precipitated was always different from the original water, to which $\mathrm{Ca}^{++}$and $\mathrm{Mg}^{++}$had been added, as only a small amount of the added $\mathrm{Mg}^{++}$precipitated.

The results of these experiments are not surprising, as experimental evidence from Baron (1960) and measurement of growth rates of natural dolomite by Peterson et al. (1966) show that dolomite formation is an extremely slow process, in which the solid-state diffusion of $\mathrm{Ca}^{++}$and $\mathrm{Mg}^{++}$in the carbonate lattice are probably rate-determining steps. It is interesting to note that the lower the initial $\mathrm{Mg} / \mathrm{Ca}$ ratio in the experimental solutions used, the higher the amount of Mg-calcite formed, and the lower the amount of $\mathrm{Mg}$ in the calcite lattice. At high supersaturations and in solutions with high $\mathrm{Mg} / \mathrm{Ca}$ ratio, $\mathrm{Mg}$ effectively blocks the surface of calcite nuclei formed, so that aragonite, unhindered by Mg-absorption, can grow freely (de Groot and Duyvis, 1966). Only at low supersaturations, when the rate of carbonate formation is slow, can a $\mathrm{Mg}$-containing $\mathrm{CaCO}_{3}$ form from solutions with a high $\mathrm{Mg} / \mathrm{Ca}$ ratio.

Table A - 1

Precipitates obtained from sample ES 129 water after addition of $\underline{\text { extra } \mathrm{CaCl}_{2}} 2, \underline{\mathrm{MgCl}}_{2}$ and $\mathrm{NaHCO}_{3}$

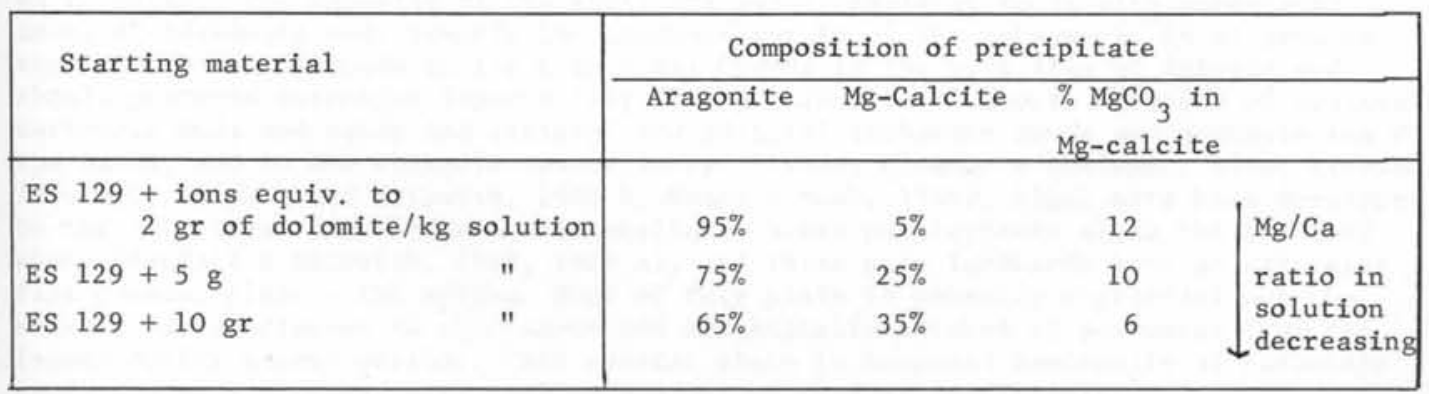

* The only possible mechanism seemed to be release of $\mathrm{CO}_{2}$ when the water came into contact with the air. $\mathrm{pH}$ measurement to evaluate the magnitude of a possible $\mathrm{CO}_{2}$ escape was not successful in the field because electrode equilibration took the same time as the turbidity development in the water. 
In another experiment the author used a saturated halite solution containing all major ions in the same ratio as they are present in sea water, except for $\mathrm{Ca}^{++}$, $\mathrm{Mg}^{++}$and $\mathrm{SO}_{4}{ }^{--} ; \mathrm{Ca}^{++}$and $\mathrm{Mg}^{++}$were present in a 6 times higher concentration than in sea water (so that $\mathrm{Mg}^{++}$concentration was equal to that in waters from pit ES 129). Sufficient $\mathrm{SO}_{4}{ }^{--}$was added to saturate the solution with gypsum. Flushing with $\mathrm{CO}_{2}$ and subsequent flushing with air resulted in formation of aragonite. After standing (in the solution) for about 2 weeks, the precipitate changed to a mixture of aragonite $(60 \%)$, Mg-calcite $(20 \%)$ and a very Ca-rich, disordered dolomite $(20 \%)$, containing about $65 \% \mathrm{CaCO}_{3}$. A disordered, very $\mathrm{Ca}-\mathrm{rich}$ dolomite can be formed by recrystallization of a $\mathrm{CaCO}_{3}$ phase in a few weeks.

These experiments, which accept the determined age of 5000 years for the dolomite, show that the ordered, Ca-rich dolomite present in pits dug in the sabkha could not have formed by instant precipitation. 